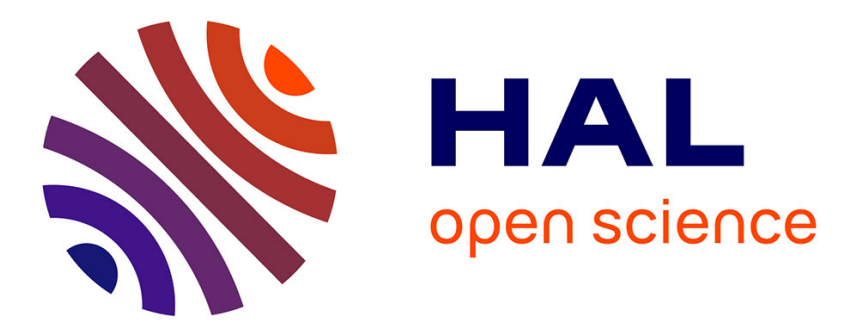

\title{
Overproduction of the Flv3B flavodiiron, enhances the photobiological hydrogen production by the nitrogen-fixing cyanobacterium Nostoc PCC 7120
}

Baptiste Roumezi, Luisana Avilan, Véronique Risoul, Myriam Brugna, Sophie Rabouille, Amel Latifi

\section{- To cite this version:}

Baptiste Roumezi, Luisana Avilan, Véronique Risoul, Myriam Brugna, Sophie Rabouille, et al.. Overproduction of the Flv3B flavodiiron, enhances the photobiological hydrogen production by the nitrogen-fixing cyanobacterium Nostoc PCC 7120. Microbial Cell Factories, 2020, 19 (1), 10.1186/s12934-020-01320-5 . hal-02539734

\section{HAL Id: hal-02539734 \\ https://hal.science/hal-02539734}

Submitted on 10 Apr 2020

HAL is a multi-disciplinary open access archive for the deposit and dissemination of scientific research documents, whether they are published or not. The documents may come from teaching and research institutions in France or abroad, or from public or private research centers.
L'archive ouverte pluridisciplinaire HAL, est destinée au dépôt et à la diffusion de documents scientifiques de niveau recherche, publiés ou non, émanant des établissements d'enseignement et de recherche français ou étrangers, des laboratoires publics ou privés. 


\section{Overproduction of the Flv3B flavodiiron, enhances the photobiological hydrogen production by the nitrogen-fixing cyanobacterium Nostoc PCC 7120}

Baptiste Roumezi ${ }^{\mathrm{a}}$, Luisana Avilan ${ }^{\mathrm{b}}$, Véronique Risoul ${ }^{\mathrm{a}}$, Myriam Brugna ${ }^{\mathrm{b}}$, Sophie Rabouille ${ }^{\mathrm{c}, \mathrm{d}}$, Amel Latifi ${ }^{\mathrm{a}}$,

a. Aix Marseille Univ, CNRS, LCB, Laboratoire de Chimie Bactérienne, Marseille, France.

b. Aix Marseille Univ, CNRS, BIP, Laboratoire de Bioénergétique et Ingénierie des Protéines, Marseille, France.

c: Sorbonne Université, CNRS, Laboratoire d'Océanographie de Villefanche, LOV, F-06230 Villefranche-sur-mer, France

d: Sorbonne Université, CNRS, Laboratoire d'Océanographie Microbienne, LOMIC, F-66650 Banyuls-sur-mer, France

* : latifi@imm.cnrs.fr

Keywords: Cyanobacteria, Flavodiiron, Heterocyte, Hydrogen, Hydrogenase

Running title: Flv3B and $\mathrm{H}_{2}$ production 


\begin{abstract}
30 Abstract
31 Background:

32 The ability of some photosynthetic microorganisms, particularly cyanobacteria and microalgae, 33 to produce hydrogen $\left(\mathrm{H}_{2}\right)$ is a promising alternative for renewable, clean-energy production. 34 However, the most recent, related studies point out that much improvement is needed for 35 sustainable cyanobacterial-based $\mathrm{H}_{2}$ production to become economically viable. In this study, 36 we investigated the impact of induced $\mathrm{O}_{2}$-consumption on $\mathrm{H}_{2}$ photoproduction yields in the 37 heterocyte-forming, $\mathrm{N}_{2}$-fixing cyanobacterium Nostoc PCC7120.
\end{abstract}

38 Results:

39 The $f l v 3 B$ gene, encoding a flavodiiron protein naturally expressed in Nostoc heterocytes, was 40 overexpressed. Under aerobic and phototrophic growth conditions, the recombinant strain 41 displayed a significantly higher $\mathrm{H}_{2}$ production than the wild type. Nitrogenase activity assays 42 indicated that $f l v 3 B$ overexpression did not enhance the nitrogen fixation rates. Interestingly, 43 the transcription of the hox genes, encoding the NiFe Hox hydrogenase, was significantly 44 elevated, as shown by the quantitative RT-PCR analyses.

\title{
45 Conclusion:
}

46 We conclude that the overproduced Flv3B protein might have enhanced $\mathrm{O}_{2}$-consumption, thus 47 creating conditions inducing hox genes and facilitating $\mathrm{H}_{2}$ production. The present study clearly 48 demonstrates the potential to use metabolic engineered cyanobacteria for photosynthesis driven $49 \mathrm{H}_{2}$ production. 


\section{Background}

Development of renewable fuel as a clean alternative to fossil fuels is nowadays strongly needed. Besides solar energy, which represents the most abundant renewable energy, hydrogen $\left(\mathrm{H}_{2}\right)$ is regarded as an attractive option for its high energy content and null ecological impact: its combustion only releases water as a byproduct. In this regard, growing autotrophic, photosynthetic organisms (cyanobacteria and algae) to yield $\mathrm{H}_{2}$ with minimized energy supply is a very promising alternative to fossil fuels.

In cyanobacteria, $\mathrm{H}_{2}$ is produced by two different enzymes: hydrogenase and nitrogenase. In diazotrophic strains, $\mathrm{H}_{2}$ is formed as a by-product of $\mathrm{N}_{2}$ fixation activity performed by the nitrogenase. However, the nitrogenase is often associated to an uptake hydrogenase, encoded by the hup genes that catalyze the oxidation of $\mathrm{H}_{2}$ into protons; the amount of $\mathrm{H}_{2}$ produced during nitrogen fixation is thus rather limited [1]. The second type of enzymes producing $\mathrm{H}_{2}$ are hydrogenases ( $\mathrm{H}_{2}$ ases). Bidirectional $\mathrm{NiFe} \mathrm{H}_{2}$ ases (called Hox), which catalyze both $\mathrm{H}_{2}$ oxidation and proton reduction, are largely distributed across the cyanobacterial phylum [2,3]. They form a heteropentamer with a $\mathrm{H}_{2}$ ase part (Hox YH) and a diaphorase part (HoxEFU). The physiological function of Hox hydrogenases in cyanobacteria is not well understood but they may serve as electron valve during photosynthesis in the unicellular cyanobacterium Synechocystis sp. PCC 6803 [4]. The expression of hox genes is induced in dark and/or anaerobic conditions [5] and is under the control of the regulators LexA and two members of the AbrB family (antibiotic resistance protein B) [6-8]. The sensitivity of cyanobacterial bidirectional $\mathrm{H}_{2}$ ases to oxygen $\left(\mathrm{O}_{2}\right)$ and the fact that their activity occurs in the dark or under anaerobic conditions are the major obstacles to obtaining efficient solar driven production of $\mathrm{H}_{2}$ in cyanobacteria. Several strategies have so far been adopted to overcome the limits of the natural $\mathrm{H}_{2}$-evolving mechanisms in cyanobacteria (for a review see [9]). 
During photosynthesis, $\mathrm{O}_{2}$ can be reduced to water through an enzymatic process involving

flavodiiron proteins (Flvs) [10]. In cyanobacteria, Flvs catalyze the reduction of $\mathrm{O}_{2}$ into water using NADPH as an electron donor [11] and play a critical role during growth under fluctuating light regimes [12]. The filamentous heterocyte-forming cyanobacterium Anabaena/Nostoc PCC7120 (hereafter Nostoc) produces four Flvs proteins in the vegetative cells (Flv1A, Flv2, Flv3A, and Flv4) and two Flvs (Flv1B and Flv3B) specific to the heterocyte [13]. The Flv3B protein mediates light-induced $\mathrm{O}_{2}$-uptake in the heterocyte, which benefits nitrogenase activity by providing a protection mechanism against oxidation [14]. In addition, the $4 f l v 3 B$ mutant displayed a broad effect on gene expression, which indicates that a regulation process links gene transcription to $\mathrm{O}_{2}$ level in the heterocyte [14].

We recently reported that decreasing the $\mathrm{O}_{2}$ level inside the heterocyte by producing the cyanoglobin GlbN allowed it to host an active $\mathrm{FeFe} \mathrm{H}_{2}$ ase from Clostridium acetobutylicum. The recombinant strain displayed a significant $\mathrm{H}_{2}$-production yield under phototrophic conditions [15]. These data suggest that engineering approaches increasing the anaerobiosis inside the heterocyte can be highly profitable for the activity of $\mathrm{O}_{2}$-sensitive enzymes. To go further, we investigate here the impact of an overproduction of the flavodiiron Flv3B protein on the production of $\mathrm{H}_{2}$ in Nostoc. We demonstrate that the recombinant strain produces on average 10-fold more $\mathrm{H}_{2}$ than the parental strain and that the expression of the hox genes is induced in this genetic background.

\section{Results}

Construction and characterization of a Nostoc recombinant strain overexpressing the $f l v 3 B$ gene 
In a transcriptomic study using an RNAseq approach, the transcription of $f l v 3 B$ (all0178) gene

99 was induced 12 hours after nitrogen starvation [16]. In order to specifically overexpress the $f l v 3 B$ gene in the heterocytes without competing with the natural promoter of this gene, we decided to place it under the control of a heterocyte-specific promoter whose transcription is induced at the same time than $f l v 3 B$. For this, we analyzed the transcription of $f l v 3 B$ throughout the differentiation process by quantitative RT-PCR. We also concomitantly monitored the transcription of the patB gene, known to be expressed after the initiation of heterocytes development [17]. flv3B and patB genes showed very similar transcription profile (Figure 1). Both genes were induced 18 hours after nitrogen stepdown and their transcription increased through the development program (compare Figure 1A and 1B). The patB promoter was therefore chosen to drive $f l v 3 B$ overexpression in Nostoc, and the resultant recombinant strain was named WT/patB-flv3B. As a first step in the characterization of this strain, we checked the overexpression of $f l v 3 B$ in response to nitrogen starvation. We first carried out quantitative RTPCR analyses and expressed the amount of $f l v 3 B$ transcripts in the recombinant strain relatively to their amount in the wild type. Results reveal a more than 10 -fold increase in $f l v 3 B$ gene expression in the recombinant strain, also starting much sooner after nitrate depletion, indicating that $f l v 3 B$ gene was strongly overexpressed (Figure 1C). Because Flv3B from Nostoc and FlvB from Chlamydomonas reinhardtii amino acid sequences present $51 \%$ identity (Figure S1), we hypothesized that antibodies produced against FlvB from C. reinhardtii [18] could cross-react with Flv3B and hence could be used to analyze the amount of Flv3B protein in Nostoc. Since Flv1B from Nostoc displays 30\% identity with FlvB from C. reinhardtii, the antiFlvB antibodies could also cross-react with this protein. However, as only the $f l v 3 B$ gene was overexpressed, we assumed that FlvB antibodies could help assessing Flv3B overproduction. In the western blot analyses, the amount of RbcL protein served to check that equal amounts of proteins were loaded in each condition [19]. Data on Figure 1D show that a protein of the 
expected size of Flv3B (64 kDa) was detected only in BG11 0 medium (without nitrate), which is in agreement with $f l v 3 B$ gene being specific to the heterocyte [13]. Moreover, this protein accumulated at a higher level in the $\mathrm{WT} /$ pat $B-f l v 3 B$ strain. Altogether, these results indicate that the $f l v 3 B$ gene was overexpressed in the recombinant strain. The WT/patB-flv $3 B$ strain showed similar growth efficiency than the wild type under both nitrogen replete and deplete conditions (Figure 2A, Table 1), and both strains differentiated heterocytes equally well (Figure 2B). The frequency of heterocytes along the filament was similar between the two strains, with 12 vegetative cells on average in between two heterocytes (Figure 2C). Given that the overexpression of $f l v 3 B$ did not impair the growth ability of the strain, we proceeded with an analysis of its impact on $\mathrm{H}_{2}$-production.

\section{$f l v 3 B$ overexpression in the heterocyte powers $\mathrm{H}_{2}$-production}

The sensitivity of $\mathrm{H}_{2}$ ases and nitrogenase to $\mathrm{O}_{2}$ is an important limitation to $\mathrm{H}_{2}-$ photoproduction. By promoting $\mathrm{O}_{2}$ consumption in the heterocyte, the Flv3B protein is ought to protect enzymes evolving $\mathrm{H}_{2}$. To test this hypothesis, the wild type and the $\mathrm{WT} / p a t B-f l v 3 B$ strains were first grown exponentially under aerobic conditions in nitrate replete medium. $\mathrm{H}_{2}-$ production yield was then measured and compared after cells were transferred to nitratedepleted medium. The recombinant strain produced 10 to 30 -fold more $\mathrm{H}_{2}$ than the wild type under the same conditions (Figure $3 \mathrm{~A}$ ). $\mathrm{H}_{2}$ production increased with the experienced light irradiance, with the highest yield obtained under $60 \mu \mathrm{E} \cdot \mathrm{m}^{-2}$. Flv3B overproduction is thus an efficient way to enhance $\mathrm{H}_{2}$ photoproduction in Nostoc.

\section{The presence of the uptake $\mathbf{H}_{2}$ ase is required for a maximal $\mathbf{H}_{2}$ production}

144 Since the uptake $\mathrm{H}_{2}$ ase consumes the $\mathrm{H}_{2}$ produced by the nitrogenase in the heterocyte and 145 since its deletion enhanced $\mathrm{H}_{2}$ production [20], we investigated whether a deletion of hupL gene, encoding the large subunit of the uptake $\mathrm{H}_{2}$ ase would show a cumulative effect with 
Flv3B overproduction. For this purpose, a deletion of hupL was constructed and the resultant strain transformed with the patB-flv3B containing plasmid. The deletion of hupL gene in an otherwise wild type background increased the $\mathrm{H}_{2}$ production level, which is in agreement with data published previously [20] (Figure 3B). However, the absence of a further enhanced $\mathrm{H}_{2}$ production following the overproduction of Flv3B in the $\Delta h u p L$ strain was unexpected. Intriguingly, the $\Delta h u p L / p a t B-f l v 3 B$ strain produced 3.5-fold less $\mathrm{H}_{2}$ than the WT/patB-flv3B strain (Figure 3B).

\section{Flv3B overproduction does not stimulate nitrogenase activity}

The deletion of the $f l v 3 B$ gene was shown to result in a decrease in both the amount of nitrogenase subunits and nitrogenase activity [14]. Therefore, the increased $\mathrm{H}_{2}$ production in the $f l v 3 B$ overproducing strain could be a consequence of an increase in the activity of the nitrogenase. To test this hypothesis, we monitored nitrogenase activity in exponentially growing cultures after their transfer to a medium devoid of combined nitrogen. Results demonstrated that the overproduction of Flv3B protein did not enhance nitrogenase activity (Table 1). Therefore, the effect of Flv3B on $\mathrm{H}_{2}$ production is unlikely to result from nitrogenase activity.

\section{Flv3B overproduction induces the expression of the bidirectional $\mathrm{H}_{2}$ ase encoding genes}

164 Since the only other enzyme able to produce $\mathrm{H}_{2}$ in cyanobacteria is the bidirectional $\mathrm{Hox}_{2}$ ase, 165 we analyzed whether an induced expression of hox genes then results from the overproduction 166 of Flv3B. The hoxH and hoxY genes encoding the $\mathrm{H}_{2}$ ase subunits as well as the hoxE,F,U genes 167 encoding the diaphorase subunits belong to two separate operons [21]. To evaluate the 168 expression of these operons, the transcription of two genes from each operon (hoxH, $Y$ and 169 hoxE,F) was comparatively monitored in the wild type and the recombinant strains. Quantitative RT-PCR analysis was used to evaluate the transcription of these four genes after 
171 transfer of the strains into nitrogen deplete conditions to induce $f l v 3 B$ expression. The

transcription of the four hox genes was weak in the wild type strain (Figure 4 A,B; Figure 5 A,B), which is in agreement with the fact that the hox genes are not expressed under aerobic conditions [21]. However, in the WT/patB-flv3B strain, 18 hours after nitrogen step down, the hoxE,F, $H$ and $Y$ transcripts level were on average 10-fold higher than in the wild type (Figure 4 C,D and Figure 5 C,D). The expression of the two hox operons encoding the $\mathrm{H}_{2}$ ase and diaphorase proteins is therefore induced in the strain overexpressing the $f l v 3 B$ gene under the heterocyte specific promoter patB. Consequently, the effect of $f l v 3 B$ overexpression on $\mathrm{H}_{2}$ production may be mediated by the induction of hox genes.

\section{Discussion}

181 In this work we show that overexpression of $f l v 3 B$ gene from a promoter specific to the heterocyte enhanced the production of $\mathrm{H}_{2}$ in aerobic cultures of Nostoc. So far, the only conditions in which $\mathrm{H}_{2}$-evolution had been recorded in aerobically grown Nostoc were the use of mutants lacking the HupL subunit of the uptake $\mathrm{H}_{2}$ ase or the last step of the maturation system of this $\mathrm{H}_{2}$ ase [20] [22]. $\mathrm{H}_{2}$ evolution mediated by Flv3B overproduction presents the advantage of sustaining the protective effect of the uptake $\mathrm{H}_{2}$ ase on the nitrogenase.

By studying the phenotype of a $\Delta f l v 3 B$ mutant of Nostoc, Ermakova et. al [14] showed that Flv3B protected nitrogenase through light-induced $\mathrm{O}_{2}$ consumption inside the heterocytes. The effect of Flv3B overproduction evidenced in our work could therefore result from a stimulated nitrogenase activity. But the recombinant strain displayed similar nitrogenase activity as the wild type (Table 1), proof that another mechanism operates to enhance $\mathrm{H}_{2}$ production.

In $C$. reinhardtii, the existence of intracellular microoxic niches in the chloroplast preserve FeFe-hydrogenase activity and support continuous $\mathrm{H}_{2}$ production during growth in aerobic cultures [23]. The same authors suggested that Flvs proteins were involved in this process [23]. 
A similar mechanism may be proposed to explain the effect of the Flv3B protein overproduction

on $\mathrm{H}_{2}$ evolution, in which the decrease in $\mathrm{O}_{2}$ concentration in the heterocyte would reinforce the anaerobiosis in this cell type, thus promoting $\mathrm{H}_{2}$ ase synthesis and/or activity. We studied the transcription of hox genes encoding the bidirectional $\mathrm{H}_{2}$ ase as their induction is known to be concomitant to high $\mathrm{H}_{2}$ ase activity [21]. Data in Figures 4 and 5 indicate that $f l v 3 B$ overproduction led to a substantial induction of $h o x E, F, H, Y$ genes expression that can explain the $\mathrm{H}_{2}$ production measured in this strain. The LexA transcriptional factor was proposed to regulate hox genes transcription in Nostoc [21]. In the unicellular cyanobacterium Synechocystis PCC6803, LexA was suggested to act as a transducer of the intracellular redox state, rather than of the SOS response as in E. coli [24]. Based on this information, we suggest that an increased $\mathrm{O}_{2}$-uptake driven by Flv3B overproduction can modify the redox state in the heterocytes, resulting in the observed induction of hox genes transcription.

Surprisingly, and contrary to what happens in the wild type background, the lack of the uptake $\mathrm{H}_{2}$ ase in the WT/patB-flv $3 B$ strain led to a decrease in $\mathrm{H}_{2}$ production (Figure $3 \mathrm{~B}$ ). As the $\mathrm{H}_{2}$ ases are bidirectional enzymes, a possible interpretation of this result is that the Hup enzyme is responsible of the $\mathrm{H}_{2}$ production observed in this recombinant strain. However, this is rather 211 unlikely since it was demonstrated that the Hup $\mathrm{H}_{2}$ ase is not able to produce $\mathrm{H}_{2}$ at any 212 significant rate, and is considered to react only in the uptake direction $[1,25]$. Through the 213 oxidation of $\mathrm{H}_{2}$, the Hup $\mathrm{H}_{2}$ ase provides electrons to the photosynthesis and respiratory 214 processes [1] (Figure 6). Since the Hox $\mathrm{H}_{2}$ ase was suggested to use ferredoxin as reducing 215 partner rather than $\mathrm{NAD}(\mathrm{P}) \mathrm{H}$ as previously admitted (reviewed in [9]), this enzyme may benefit 216 from the electrons generated by the Hup $\mathrm{H}_{2}$ ase through regeneration of the reduced ferredoxin 217 pool (Figure 6). This could explain the negative impact of the hupL deletion on the $\mathrm{H}_{2-}$ 218 production yield in the WT/patB-flv3B strain (Figure 6). Our data show that metabolic 
engineering approaches are particularly relevant in the use of photosynthetic bacteria for biofuel production.

\section{Conclusion}

In the present study, the $f l v 3 B$ gene was specifically overexpressed in the heterocyte of Nostoc under the control of the $p a t B$ promoter. The overproduction of the Flv3B flavodiiron enhanced the $\mathrm{H}_{2}$ production yield by a factor of ten on average, which is not to be attributed to the nitrogenase since no increase in the nitrogenase activity was observed. The transcription of the hox genes was induced in the recombinant strain expressing the flv $3 B$ gene, suggesting that the additional $\mathrm{H}_{2}$ produced relates to the activity of the bidirectional $\mathrm{H}_{2}$ ase. Facilitating the consumption of $\mathrm{O}_{2}$ inside the heterocyte thus appears as a relevant step towards the design of an optimized Nostoc strain for $\mathrm{H}_{2}$ production. This paves the way to further improvement to achieve sustainable production of $\mathrm{H}_{2}$ by air-grown cyanobacteria.

\section{Methods}

\section{Growth conditions and heterocytes induction}

233 Cyanobacterial strains were grown in BG11 medium (nitrate replete) at $30{ }^{\circ} \mathrm{C}$ under continuous 234 illumination $\left(30 \mu \mathrm{E} \mathrm{m}^{-2} \mathrm{~s}^{-1}\right)$. Cultures of recombinant strains were supplemented with neomycin $235\left(50 \mu \mathrm{g} \mathrm{mL}^{-1}\right)$. Heterocyte formation was induced by transferring the exponentially growing 236 cultures $(\mathrm{OD} 750=0.8)$ to $\mathrm{BG} 11_{0}(\mathrm{BG} 11$ devoid of sodium nitrate) by filtration $(0.2 \mu \mathrm{m}$ pore 237 size filters, Sigma) and resuspension of cells into the nitrate-free medium. The growth was 238 maintained for 4 days. The presence of heterocytes was confirmed by light microscopy and 239 their distribution within filaments was rated visually by counting the number of vegetative cells 240 between two heterocytes. At least 400 total vegetative cells were counted for each strain.

241 In the $\mathrm{H}_{2}$ production experiments, the strains were grown under continuous illumination of 20 $242 \mu \mathrm{E} \mathrm{m}^{-2} \mathrm{~s}^{-1}$ or $60 \mu \mathrm{E} \mathrm{m^{-2 } \mathrm { s } ^ { - 1 } .}$ 


\section{Construction of plasmids and strains}

244 To construct the Flv3B overproducing strain, the promoter region of patB (all2512, $500 \mathrm{bp}$ upstream the start codon) was amplified by PCR from Nostoc sp. PCC 7120 genomic DNA using the ppatB forward and ppatB reverse primers (Table 3). The ppatB reverse primer contained a multiple cloning site (ApaI, ClaI, BamHI, SalI, ScaI, EcoRI). The amplified promoter was cloned into BglII and EcoRI restriction sites of the pRL25T plasmid [26], yielding the pRL25T-patB plasmid. The open reading frame of $f l v 3 B$ gene was amplified using the $f l v 3 B$ forward and reverse primers (Table3), and cloned into the ApaI and ScaI restriction sites of the pRLpatB. The recombinant plasmid (pRL25T-patB-flv3B) was analyzed by sequencing (Millegen). Conjugation of Nostoc was performed as described in reference [27]. Briefly, E. coli strains (bearing the replicative pRL25T-patB-flv3B and the RP-4 conjugative plasmid) grown to exponential growth phase, were mixed to an exponentially grown Nostoc culture. The mixture was plated on BG11 plates and Neomycin was added 24 hours later for plasmid selection. Plasmid extraction was used to analyze the obtained recombinant clones.

Deletion of the hupL gene, yielding the ShetL strain, was obtained by homologous recombination replacing the hupL3' gene (all0687C) with the gene encoding the spectinomycin/streptomycin resistance ( $\mathrm{Sp} / \mathrm{Sm}$ cassette hereafter). For this purpose, the upstream and downstream $1500 \mathrm{bp}$ flanking the hupL3' gene were amplified form Nostoc genomic DNA using the all0678 forward/ all0678 reverse and the Strp-all0678 forward/ Strpall0678 forward, respectively; The Sp/Sm cassette was amplified using the Strp forward/Strp reverse primers (Table 3), using the pBAD42 plasmid (Addgen) as template. Gibson's assembly technique (New-England Biolabs) was applied to insert the three resulting fragments into the suicide pRL271 vector linearized by SpeI. The resulting recombinant plasmid was conjugated into Nostoc as described above. The initial conjugants were selected by screening for resistance to $5 \mu \mathrm{g} / \mathrm{mL}$ of $\mathrm{Sm}$, and the resulting cells were then grown on BG11 plates containing $5 \%$ 
268 sucrose to select double recombinants. Genomic DNA of the recombinant cells were analyzed

270 The strains and plasmids used in this study are listed in Table 2.

\section{RNA Preparation and Reverse Transcription}

RNAs were prepared using the Qiagen RNA extraction kit (Qiagen) following the manufacturer instructions. An extra TURBO DNase (Invitrogen) digestion step was undergone to eliminate the contaminating DNA. The RNA quality was assessed by tape station system (Agilent). RNAs were quantified spectrophotometrically at $260 \mathrm{~nm}$ (NanoDrop 1000; Thermo Fisher Scientific). For cDNA synthesis, $1 \mu \mathrm{g}$ total RNA and $0.5 \mu \mathrm{g}$ random primers (Promega) were used with the GoScript ${ }^{\mathrm{TM}}$ Reverse transcriptase (Promega) according to the manufacturer instructions.

278 Quantitative Real-Time-PCR for Transcriptional Analyses

279 Quantitative real-time PCR (qPCR) analyses were performed on a CFX96 Real-Time System 280 (Bio-Rad). The reaction volume was $15 \mu \mathrm{L}$ and the final concentration of each primer was 0.5 $281 \mu \mathrm{M}$. The qPCR cycling parameters were $95^{\circ} \mathrm{C}$ for $2 \mathrm{~min}$, followed by 45 cycles of $95^{\circ} \mathrm{C}$ for 5 $282 \mathrm{~s}, 55^{\circ} \mathrm{C}$ for $60 \mathrm{~s}$. A final melting curve from $65^{\circ} \mathrm{C}$ to $95^{\circ} \mathrm{C}$ was added to determine the specificity 283 of the amplification. To determine the amplification kinetics of each product, the fluorescence 284 derived from the incorporation of BRYT Green ${ }^{\circledR}$ Dye into the double-stranded PCR products 285 was measured at the end of each cycle using the GoTaq ${ }^{\circledR}$ qPCR Master Mix 2X Kit (Promega). 286 The results were analysed using Bio-Rad CFX Maestro software, version 1.1 (Bio-Rad, France). 287 The $r n p B$ gene was used as a reference for normalization. A technical duplicate was performed 288 for each point. The amplification efficiencies of each primer pairs were 80 to $100 \%$. All of the 289 primer pairs used for qPCR are reported in Table 3.

\section{Western blot analysis}


291 Proteins $(75 \mu \mathrm{g})$ extracted from cyanobacterial strains were fractionated by performing SDS-

PAGE $12 \%$, and transferred to nitrocellulose membranes before being revealed with specific polyclonal antibodies. Immune complexes were detected with anti-rabbit peroxidaseconjugated secondary antibodies (Promega) and enhanced chemoluminescence reagents (Pierce). Anti-FlvB antibodies, developed against the FlvB protein of $C$. reinhardtii [18], were used at a 1: 1000 dilution. Anti-Rbcl antibodies (Agrisera) were used a 1: 5000 dilution.

\section{$\mathrm{H}_{2}$ production assays}

Nostoc wild type strain and its derivatives were grown as described above for heterocyte induction. Chlorophyll $a$ concentration was quantified according to the following method: 1 $\mathrm{mL}$ of culture was centrifuged $\left(5 \mathrm{~min}, 6700 \mathrm{~g}, 4^{\circ} \mathrm{C}\right.$ ), the pellet was resuspended in $1 \mathrm{~mL}$ of cold methanol and incubated at $4^{\circ} \mathrm{C}$ for 30 minutes under shaking. Cells were then harvested (5 min, $6700 \mathrm{~g}, 4^{\circ} \mathrm{C}$ ) and absorbance of the supernatant was measured at $665 \mathrm{~nm}$ and $720 \mathrm{~nm}$. The chlorophyll $a$ concentration was calculated according to the formula: $\left[\mathrm{Chl}\right.$ a] $=12,9447$ ( $\mathrm{A}_{665-}$ $\mathrm{A}_{720}$ ) and expressed in $\mu \mathrm{g}$ of Chla/mL of culture [28]. A 40-mL volume of cell culture was then harvested $\left(5 \mathrm{~min}, 6700 \mathrm{~g}, 4^{\circ} \mathrm{C}\right)$ and cells were resuspended in sterile nitrate-depleted medium

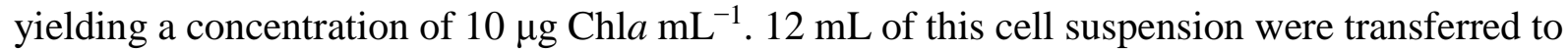
Hungate tubes (leaving a 4.4-mL head space volume). The vials were sparged with Argon (Ar), and the samples were maintained under illumination $\left(20\right.$ or $60 \mu \mathrm{mol}$ photons $\left.\mathrm{m}^{-2} \mathrm{~s}^{-1}\right)$ for 96 hours. $100 \mu \mathrm{L}$ of headspace gas was removed every 12 hours using a gastight syringe and injected into a gas chromatography system (Agilent 7820) equipped with a thermal conductivity detector and a HP-plot Molesieve capillary column ( $30 \mathrm{~m}, 0.53 \mathrm{~mm}, 25 \mu \mathrm{m})$, using argon as the carrier gas, at a flow rate of $4.2 \mathrm{~mL} / \mathrm{min}$, an oven temperature of $30{ }^{\circ} \mathrm{C}$ and a detector temperature of $150{ }^{\circ} \mathrm{C} . \mathrm{H}_{2}$ was quantified according to a standard calibration curve. $\mathrm{H}_{2}$ production rate was expressed as mol of $\mathrm{H}_{2}$ produced per mg of Chlorophyll. 
An on-line acetylene reduction assay [29] was used to measure nitrogenase activity. Briefly, cyanobacterial strains were grown in batch cultures under light/dark cycles of 12 hours/12 hours. Nitrogenase activity was monitored for 20 hours. Before the onset of nitrogenase activity, Nostoc cultures were transferred to a GF/F filter (Whatman, $47 \mathrm{~mm}$ ) and placed in a custommade, light and temperature-controlled gas flow-through incubator connected to the gas chromatograph. Acetylene represented $10 \%$ of the gas mixture and the total gas flow rate was $11 \mathrm{~h}^{-1}$. Ethylene production was measured every $10 \mathrm{~min}$ by gas chromatography using an Agilent 7890 equipped with an auto-injector and a photoionization detector.

\section{References}

1. Houchins JP, Burris RH: Light and dark reactions of the uptake hydrogenase in anabaena 7120. Plant Physiol 1981, 68:712-716.

2. Puggioni V, Tempel S, Latifi A: Distribution of Hydrogenases in Cyanobacteria: A PhylumWide Genomic Survey. Front Genet 2016, 7:223.

3. Tamagnini P, Leitao E, Oliveira P, Ferreira D, Pinto F, Harris DJ, Heidorn T, Lindblad P: Cyanobacterial hydrogenases: diversity, regulation and applications. FEMS Microbiol Rev 2007, 31:692-720.

4. Cournac L, Guedeney G, Peltier G, Vignais PM: Sustained photoevolution of molecular hydrogen in a mutant of Synechocystis sp. strain PCC 6803 deficient in the type I NADPHdehydrogenase complex. J Bacteriol 2004, 186:1737-1746.

5. Kiss $E$, Kos $P B$, Vass I: Transcriptional regulation of the bidirectional hydrogenase in the cyanobacterium Synechocystis 6803. J Biotechnol 2009, 142:31-37.

6. Dutheil J, Saenkham P, Sakr S, Leplat C, Ortega-Ramos M, Bottin H, Cournac L, CassierChauvat $C$, Chauvat F: The AbrB2 autorepressor, expressed from an atypical promoter, represses the hydrogenase operon to regulate hydrogen production in Synechocystis strain PCC6803. J Bacteriol 2012, 194:5423-5433.

7. Gutekunst K, Phunpruch S, Schwarz C, Schuchardt S, Schulz-Friedrich R, Appel J: LexA regulates the bidirectional hydrogenase in the cyanobacterium Synechocystis sp. PCC 6803 as a transcription activator. Mol Microbiol 2005, 58:810-823.

8. Oliveira $\mathrm{P}$, Lindblad $\mathrm{P}$ : LexA, a transcription regulator binding in the promoter region of the bidirectional hydrogenase in the cyanobacterium Synechocystis sp. PCC 6803. FEMS Microbiol Lett 2005, 251:59-66.

9. Khanna N, Lindblad P: Cyanobacterial hydrogenases and hydrogen metabolism revisited: recent progress and future prospects. Int J Mol Sci 2015, 16:10537-10561.

10. Allahverdiyeva $Y$, Suorsa M, Tikkanen M, Aro EM: Photoprotection of photosystems in fluctuating light intensities. J Exp Bot 2015, 66:2427-2436.

11. Helman Y, Tchernov D, Reinhold L, Shibata M, Ogawa T, Schwarz R, Ohad I, Kaplan A: Genes encoding A-type flavoproteins are essential for photoreduction of $\mathrm{O}_{2}$ in cyanobacteria. Curr Biol 2003, 13:230-235. 
12. Allahverdiyeva $Y$, Mustila H, Ermakova M, Bersanini L, Richaud P, Ajlani G, Battchikova N, Cournac L, Aro EM: Flavodiiron proteins Flv1 and Flv3 enable cyanobacterial growth and photosynthesis under fluctuating light. Proc Natl Acad Sci U S A 2013, 110:4111-4116.

13. Ermakova $M$, Battchikova $N$, Allahverdiyeva $Y$, Aro EM: Novel heterocyst-specific flavodiiron proteins in Anabaena sp. PCC 7120. FEBS Lett 2013, 587:82-87.

14. Ermakova M, Battchikova N, Richaud P, Leino H, Kosourov S, Isojarvi J, Peltier G, Flores E, Cournac L, Allahverdiyeva $Y$, Aro EM: Heterocyst-specific flavodiiron protein Flv3B enables oxic diazotrophic growth of the filamentous cyanobacterium Anabaena sp. PCC 7120. Proc Natl Acad Sci U S A 2014, 111:11205-11210.

15. Avilan L, Roumezi B, Risoul V, Bernard CS, Kpebe A, Belhadjhassine M, Rousset M, Brugna M, Latifi A: Phototrophic hydrogen production from a clostridial [FeFe] hydrogenase expressed in the heterocyts of the cyanobacterium Nostoc PCC 7120. Appl Microbiol Biotechnol 2018, 102:5775-5783.

16. Mitschke J, Vioque A, Haas F, Hess WR, Muro-Pastor AM: Dynamics of transcriptional start site selection during nitrogen stress-induced cell differentiation in Anabaena sp. PCC7120. Proc Natl Acad Sci U S A 2011, 108:20130-20135.

17. Jones KM, Buikema WJ, Haselkorn R: Heterocyte-specific expression of patB, a gene required for nitrogen fixation in Anabaena sp. strain PCC 7120. J Bacteriol 2003, 185:23062314.

18. Chaux F, Burlacot A, Mekhalfi M, Auroy P, Blangy S, Richaud P, Peltier G: Flavodiiron Proteins Promote Fast and Transient $\mathrm{O}_{2}$ Photoreduction in Chlamydomonas. Plant Physiol 2017, 174:1825-1836.

19. Nierzwicki-Bauer SA, Curtis SE, Haselkorn R: Cotranscription of genes encoding the small and large subunits of ribulose-1,5-bisphosphate carboxylase in the cyanobacterium Anabaena 7120. Proc Natl Acad Sci U S A 1984, 81:5961-5965.

20. Masukawa $\mathrm{H}$, Mochimaru M, Sakurai H: Disruption of the uptake hydrogenase gene, but not of the bidirectional hydrogenase gene, leads to enhanced photobiological hydrogen production by the nitrogen-fixing cyanobacterium Anabaena sp. PCC 7120. Appl Microbiol Biotechnol 2002, 58:618-624.

21. Sjoholm J, Oliveira P, Lindblad P: Transcription and regulation of the bidirectional hydrogenase in the cyanobacterium Nostoc sp. strain PCC 7120. Appl Environ Microbiol 2007, 73:5435-5446.

22. Nyberg $\mathrm{M}$, Heidorn $\mathrm{T}$, Lindblad $\mathrm{P}$ : Hydrogen production by the engineered cyanobacterial strain Nostoc PCC 7120 DeltahupW examined in a flat panel photobioreactor system. J Biotechnol 2015, 215:35-43.

23. Liran O, Semyatich R, Milrad Y, Eilenberg H, Weiner I, Yacoby I: Microoxic Niches within the Thylakoid Stroma of Air-Grown Chlamydomonas reinhardtii Protect [FeFe]-Hydrogenase and Support Hydrogen Production under Fully Aerobic Environment. Plant Physiol 2016, 172:264-271.

24. Patterson-Fortin LM, Colvin KR, Owttrim GW: A LexA-related protein regulates redoxsensitive expression of the cyanobacterial RNA helicase, crhR. Nucleic Acids Res 2006, 34:3446-3454.

25. Houchins JP, Burris RH: Comparative characterization of two distinct hydrogenases from Anabaena sp. strain 7120. J Bacteriol 1981, 146:215-221.

26. Yang $Y$, Huang $X Z$, Wang $L$, Risoul V, Zhang CC, Chen WL: Phenotypic variation caused by variation in the relative copy number of pDU1-based plasmids expressing the GAF domain of Pkn41 or Pkn42 in Anabaena sp. PCC 7120. Res Microbiol 2013, 164:127-135.

27. Cai YP, Wolk CP: Use of a conditionally lethal gene in Anabaena sp. strain PCC 7120 to select for double recombinants and to entrap insertion sequences. J Bacteriol 1990, 172:3138-3145.

28. Ritchie RJ: Consistent sets of spectrophotometric chlorophyll equations for acetone, methanol and ethanol solvents. Photosynth Res 2006, 89:27-41. 
29. Dron A, Rabouille S, Claquin P, Talec A, Raimbault V, Sciandra A: Photoperiod length paces the temporal orchestration of cell cycle and carbon-nitrogen metabolism in Crocosphaera watsonii. Environ Microbiol 2013, 15:3292-3304.

30. Wolk CP, Cai Y, Cardemil L, Flores E, Hohn B, Murry M, Schmetterer G, Schrautemeier B, Wilson R: Isolation and complementation of mutants of Anabaena sp. strain PCC 7120 unable to grow aerobically on dinitrogen. J Bacteriol 1988, 170:1239-1244.

Table 1

\begin{tabular}{|l|c|c|}
\hline \multicolumn{1}{|c|}{ Strain } & Wild type & WT/patB-flv3B \\
Measure & 0.155 & 0.155 \\
\hline $\begin{array}{l}\text { Exponential growth rate per } \\
\text { day (BG110) }\end{array}$ & 4.49 & 8.9 \\
\hline Chl $a$ content $(\mathrm{mg}$ Chl $a / \mathrm{mL})$ & 17.3 & 11.2 \\
\hline $\begin{array}{l}\text { Nitrogenase activity } \\
(\text { nmol N } / \text { mg Chla } / \mathrm{h})\end{array}$ & 0.001 & 0.00025 \\
\hline sd on nitrogenase activity &
\end{tabular}

Two independent cultures of each strain were grown as explained in the Material and Methods 418 section. For each strain, the nitrogenase activity values presented in this table were registered 419 at $\mathrm{T}=4$ hours of the light phase. Chla: chlorophyll $a$; sd: standard deviation

421 Table 2: List of the bacterial strains and the plasmids used in this study.

\begin{tabular}{|c|c|c|}
\hline Strain name & Description/ Antibiotic resistance & Origin \\
\hline Wild type & $\begin{array}{l}\text { Nostoc/Anabaena PCC } 7120 \text { wild type } \\
\text { strain }\end{array}$ & $\begin{array}{l}\text { Pasteur Cyanobacterial } \\
\text { Collection }\end{array}$ \\
\hline $\mathrm{WT} / p a t B-f l v 3 B$ & $\begin{array}{l}\text { Nostoc containing the pRL25T-patB-flv3B } \\
\text { plasmid/ }\left(\mathrm{Neo}^{\mathrm{R}}\right)\end{array}$ & This study \\
\hline$\Delta h u p L$ & $\begin{array}{l}\text { Nostoc deletion mutant of the hupL gene } \\
\left(\mathrm{Sp} / \mathrm{Sm}^{R}\right) /\end{array}$ & This study \\
\hline $\begin{array}{l}\Delta h u p L / p a t B- \\
\text { flv3B }\end{array}$ & $\begin{array}{l}\Delta \text { hupL mutant containing the pRL25T- } \\
\left.\text { patB-flv3B /(Sp/Sm }{ }^{R} \text { and } \mathrm{Neo}^{\mathrm{R}}\right)\end{array}$ & This study \\
\hline Plasmid name & Description/ Antibiotic resistance & Origin \\
\hline pRL25T & $\begin{array}{l}\text { Replication vector derived from the } \\
\text { pRL25C cosmid }\left(\mathrm{Neo}^{\mathrm{R}}\right)\end{array}$ & {$[26],[30]$} \\
\hline pRL25T-patB-flv3B & $\begin{array}{l}\text { pRL25T harboring the } f l v 3 B \text { gene under the } \\
\text { control of the patB promoter }\left(\mathrm{Neo}^{\mathrm{R}}\right)\end{array}$ & This study \\
\hline
\end{tabular}


Table 3: sequence of the primers used in this study

\begin{tabular}{|c|c|c|}
\hline Name & Sequence $\left(5^{\prime}-3^{\prime}\right)$ & Experiment \\
\hline $\begin{array}{l}\text { rnpB forward } \\
\text { rnpB reverse } \\
\text { flv3B RT forward } \\
\text { flv3B RT reverse } \\
\text { patB forward } \\
\text { patB reverse } \\
\text { hoxE forward } \\
\text { hoxE reverse } \\
\text { hoxF forward } \\
\text { hoxF reverse } \\
\text { hoxH forward } \\
\text { hoxH reverse } \\
\text { hoxY forward } \\
\text { hoxY reverse }\end{array}$ & $\begin{array}{l}\text { TCGTGAGGATAGTGCCACAG } \\
\text { GGAAGTTTCTTCCCCAGTCC } \\
\text { TTTGGTGGAAGATGTGCTGC } \\
\text { GCCAATGTAAGTTAGGCGCA } \\
\text { AGGGGCGATGTAAAGTGGAA } \\
\text { TTGACTGCTCGACTGTAGCA } \\
\text { GCGTCACCAGTATCAGCAAG } \\
\text { TGGGGCGCTAGGGAAAATAA } \\
\text { ACCCGGCTGAATCTGGTTTA } \\
\text { AAGCCTGTGTTGCGGATTTT } \\
\text { CTGGACAGGTAAACGATGCG } \\
\text { ACAAATCCGCGCTGTAATCC } \\
\text { TTTCCTTTGGTGACTGTGCG } \\
\text { GGTTGATATCGGCTGCTTGG }\end{array}$ & $\begin{array}{l}\text { Quantitative } \\
\text { analysis }\end{array}$ \\
\hline $\begin{array}{l}\text { ppat } B \text { forward } \\
\text { ppatB reverse } \\
\text { flv3B forward } \\
\text { flv3B reverse }\end{array}$ & $\begin{array}{l}\text { TATAAGATCTGTCTTTAAATATACATGGTTTGGG } \\
\text { TATAGAATTCGAGCTCGTCGACCCGGGATCCATCG } \\
\text { ATGGGCCCCATATAACTTTCTTCCCACCC } \\
\text { TAT CCCGGG ATG GTA TCG ATG TCT ACG ACC } \\
\text { TAT AGTACT TTA GTA ATA GTT GCC TAC TTT } \\
\text { GCG }\end{array}$ & Cloning of patB promoter \\
\hline $\begin{array}{l}\text { Strp forward } \\
\text { Strp reverse } \\
\text { all0678 forward } \\
\text { all0678 reverse } \\
\text { Strp-all0678 forward } \\
\text { Strp-all0678 reverse }\end{array}$ & $\begin{array}{l}\text { AATTCCCCTGCTCGCGCAGG } \\
\text { AGCTTAGTAAAGCCCTCGCT } \\
\text { TTCGATATCTAGATCTCGAGTCAATTAATGACTTTT } \\
\text { GACTAATTA } \\
\text { AGTAGACGGAGTATACTAGTGCAACTTTCGGAGC } \\
\text { G } \\
\text { CCTGCGCGAGCAGGGGAATTCATATAACTGCTGT } \\
\text { GGCA } \\
\text { AGCGAGGGCTTTACTAAGCTGTTTAAACGCAGAG } \\
\text { GGG }\end{array}$ & $\begin{array}{l}\text { Construction of the hupL } \\
\text { deleted mutant }\end{array}$ \\
\hline
\end{tabular}




\section{Legends to Figures}

\section{Figure 1: Flv3B overproduction analysis}

429 A, B, C: Quantitative RT-PCR analysis of $f l v 3 B(\mathrm{~A}, \mathrm{C})$ and patB (B, D) gene transcription. RNA 430 were collected from the wild type (A, B) or the WT/patB-flv3B (C) strain at four different times (7, 18, 24 and 48 hours) after the onset of nitrogen depletion. Each sample was measured in triplicate and the standard deviation is indicated by error bars. Values were normalized to the $r n p B$ transcript, relatively to the value obtained for the wild type strain, which was set to 1 .

D: Immunoblot analysis of the amount of Flv3B protein (upper panel) in the wild type and WT/patB-flv3B strains, carried out using antibodies produced against FlvB from Chlamydomonas reinhardtii [18]. Immunoanalysis of RbcL protein amount was carried out as a loading control (lower panel). The condition (+ Nitrate) stands for cultures performed in nitrate-containing medium, and the condition (- Nitrate) indicates cultures grown in nitrate-free medium.

\section{Figure 2: Characterization of Nostoc strain overexpressing the $f l v 3 B$ gene}

A: Growth curve of Nostoc strains grown in either nitrate-containing medium or nitrate free medium. For each curve, three independent cultures were performed. The growth was assessed during twelve days by measuring the optical density at $750 \mathrm{~nm}$. The standard deviation is indicated by error bars.

B: Light microscope images of Nostoc strains grown in nitrate-containing medium or nitratefree medium. For the last conditions, images were acquired 24 hours after nitrogen starvation. Heterocytes are indicated by black arrows.

C: Heterocyte pattern formation in the wild type and the WT/patB-flv $3 B$ strain. Strains were grown in BG11 (nitrate-containing medium) to an $\mathrm{OD}_{750}$ of 0.4 and induced to form heterocytes by transfer to 
BG-110 medium (nitrate-free medium). Vegetative cells and heterocytes were scored microscopically 24 hours after nitrogen starvation. The data shown are representative of three independent experiments

\section{Figure 3: $\mathrm{H}_{2}$ production kinetics}

A: wild type or $\mathrm{WT} / p a t B-f v l 3 B$ were grown in nitrate-containing medium until OD $750 \mathrm{nmm}=$ 0.8. Heterocyte formation was induced by transferring the strains to a nitrate-free medium during 24 hours. The strains were then incubated under light intensities of either $20 \mu \mathrm{E} / \mathrm{m}^{2}$ or $60 \mu \mathrm{E} / \mathrm{m}^{2}$, and $\mathrm{H}_{2}$ production was assessed by chromatography as explained in the methods section during four days. The values represent Means $\pm \operatorname{SEM}(\mathrm{n}=8)$.

B: wild type, WT/patB-fvl3B, $\triangle$ hupL or $\triangle h u p L / p a t B-f v l 3 B$ strains were grown under light intensities of $60 \mu \mathrm{E} / \mathrm{m}^{2}$. Hetrocyte formation and $\mathrm{H}_{2}$-production were respectively induced and performed as described above. The values represent Means \pm SEM ( $\mathrm{n}=8)$.

\section{Figure 4: hox $Y, H$ genes transcription analysis}

Quantitative RT-PCR analysis of hox $Y$ and hoxH gene transcription. RNA were collected form wild type $(\mathrm{A}, \mathrm{B})$ or $\mathrm{WT} /$ patB-fvl $3 B(\mathrm{C}, \mathrm{D})$ at different times after the onset of the nitrogen depletion step. Each sample was measured in triplicate and the standard deviation is indicated by error bars. Values were normalized to the $\operatorname{rnpB}$ transcript.

\section{Figure 5: hoxE, $F$ genes transcription analysis}

Quantitative RT-PCR analysis of hoxE and hoxF gene transcription. RNA were collected form wild type (A, B) or WT/patB-fvl $3 B(\mathrm{C}, \mathrm{D})$ at different times after the onset of the nitrogen depletion step. Each sample was measured in triplicate and the standard deviation is indicated by error bars. Values were normalized to the $\operatorname{rnpB}$ transcript.

Figure 6: Hypothetical model of $\mathrm{H}_{2}$ production in Nostoc strain overproducing Flv3B 
473 Nitrogen fixation occurring in the heterocyte produces $\mathrm{H}_{2}$ which is recycled by the $\mathrm{Hup}_{2}$ ase.

Overexpression of the $f l v 3 B$ gene increases the uptake of $\mathrm{O}_{2}$ reinforcing the microoxie inside the heterocyte. The induction of hox genes transcription leads to $\mathrm{H}_{2}$ production.

$\mathrm{Fd}_{\mathrm{red}}$ : reduced ferredoxin; $\mathrm{Fd}_{\mathrm{ox}}$ : oxidized ferredoxin. Dashed lines stand for indirect effect.

\section{Supplementary Figure 1:}

Alignment of the amino acid sequence of the Flv3B protein of Nostoc (all0178) and FlvB of Chlamydomonas reinhardtii (Cre16.g691800.t1.1).

\section{Declarations:}

\section{Ethics approval and consent to participate:}

482 Not applicable

483 Consent for publication

484 Not applicable

18-CE05-0029).

\section{Availability of data and material}

All the data supporting the conclusions of this article are included within the article and its additional file.

\section{Competing interests}

The authors declare that they do not have any conflict of interest.

\section{Funding:}

This research was supported by the "Agence Nationale pour la Recherche Scientifique" (ANR-

\section{Authors' contributions:}

AL conceived, designed the study. RB, LA, VR and SR performed the research. AL and MB supervised the research. AL, LA and SR analyzed the data. AL wrote the manuscript. 
2

6498 The authors thank Yann Denis from the "Plateforme Transcriptomique, FR3479 IMM" for the 499 quantitative RT-PCR analysis and Dr Gilles Peltier for providing the anti-FlvB antibodies. 

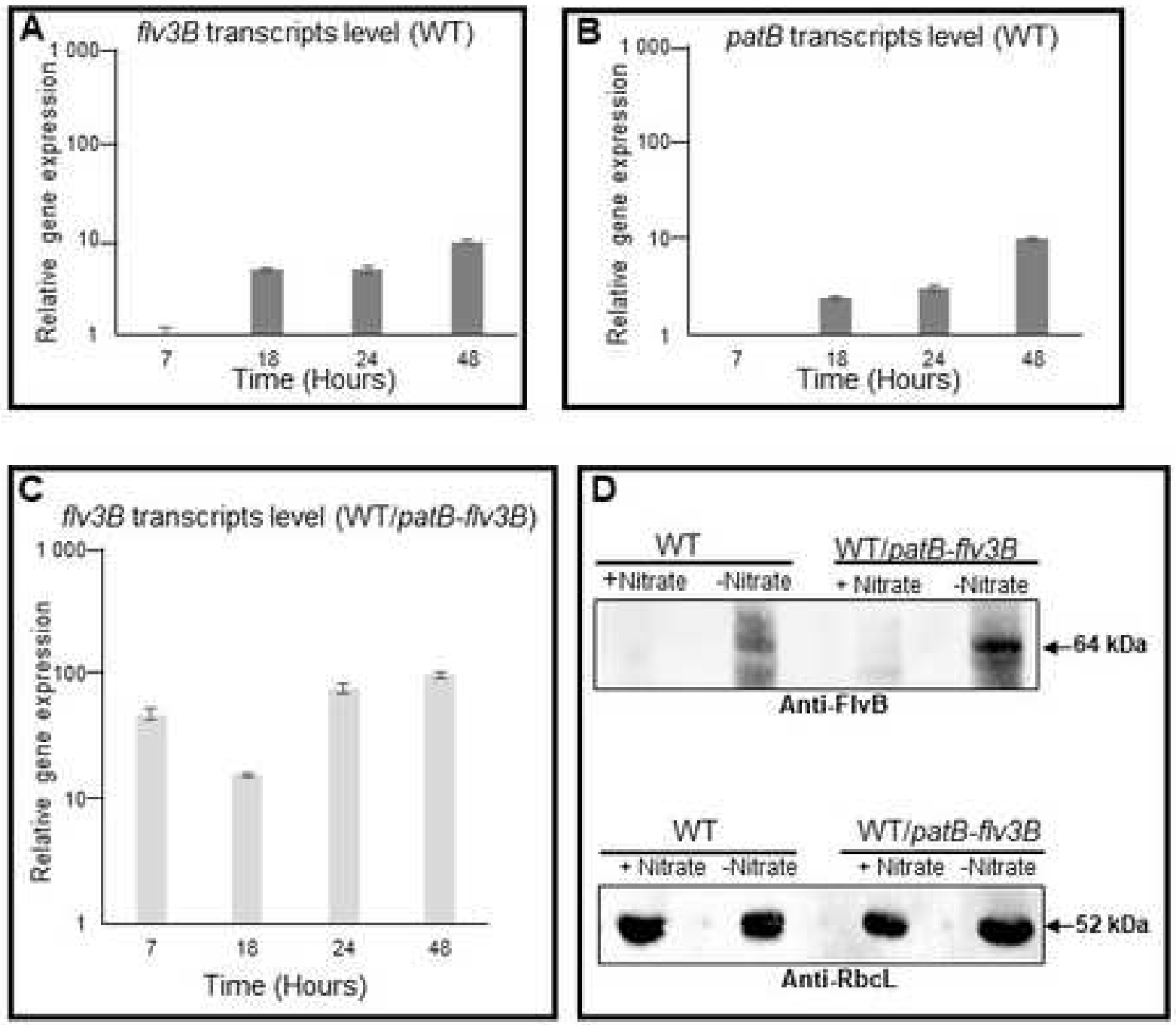

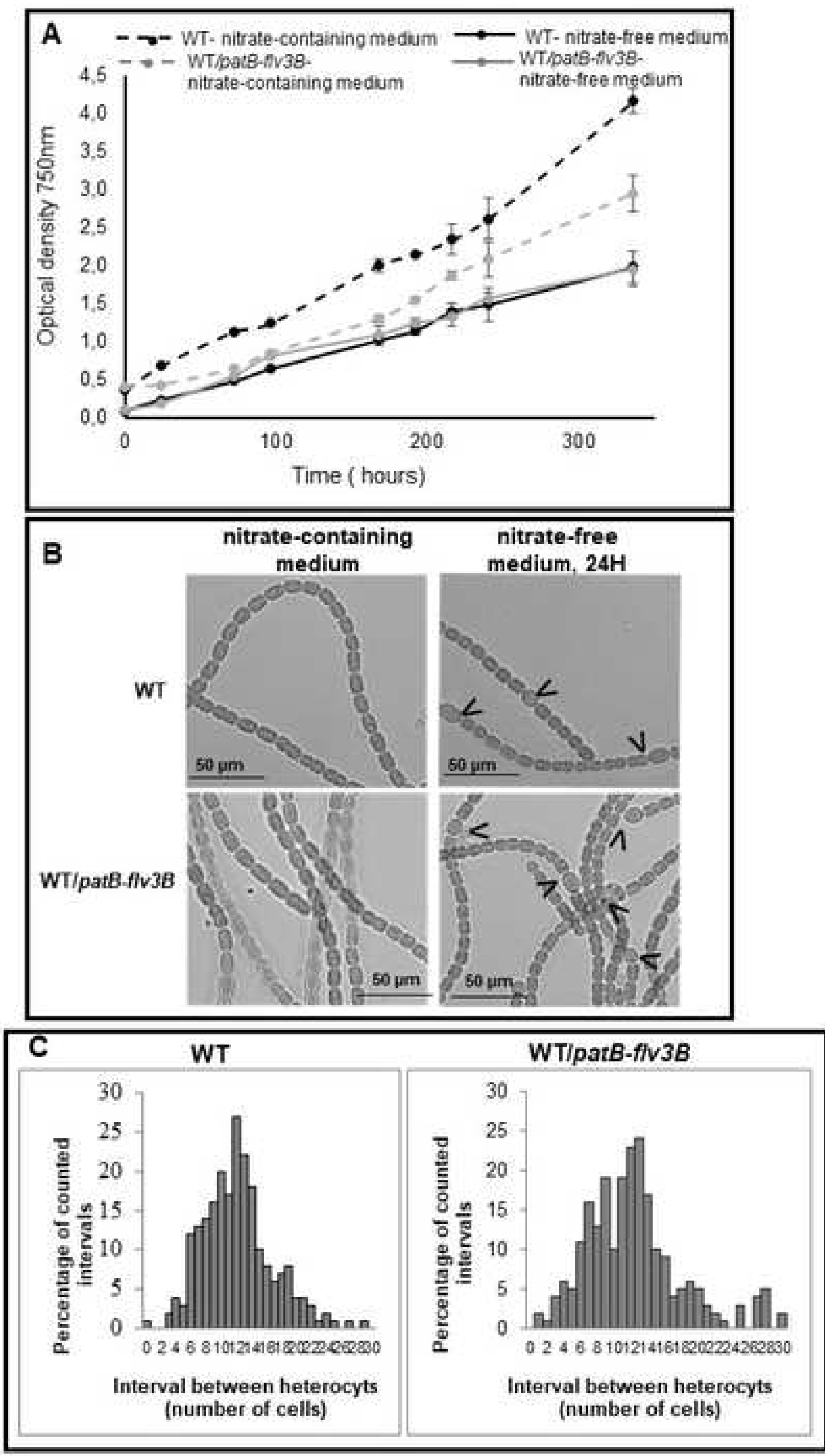

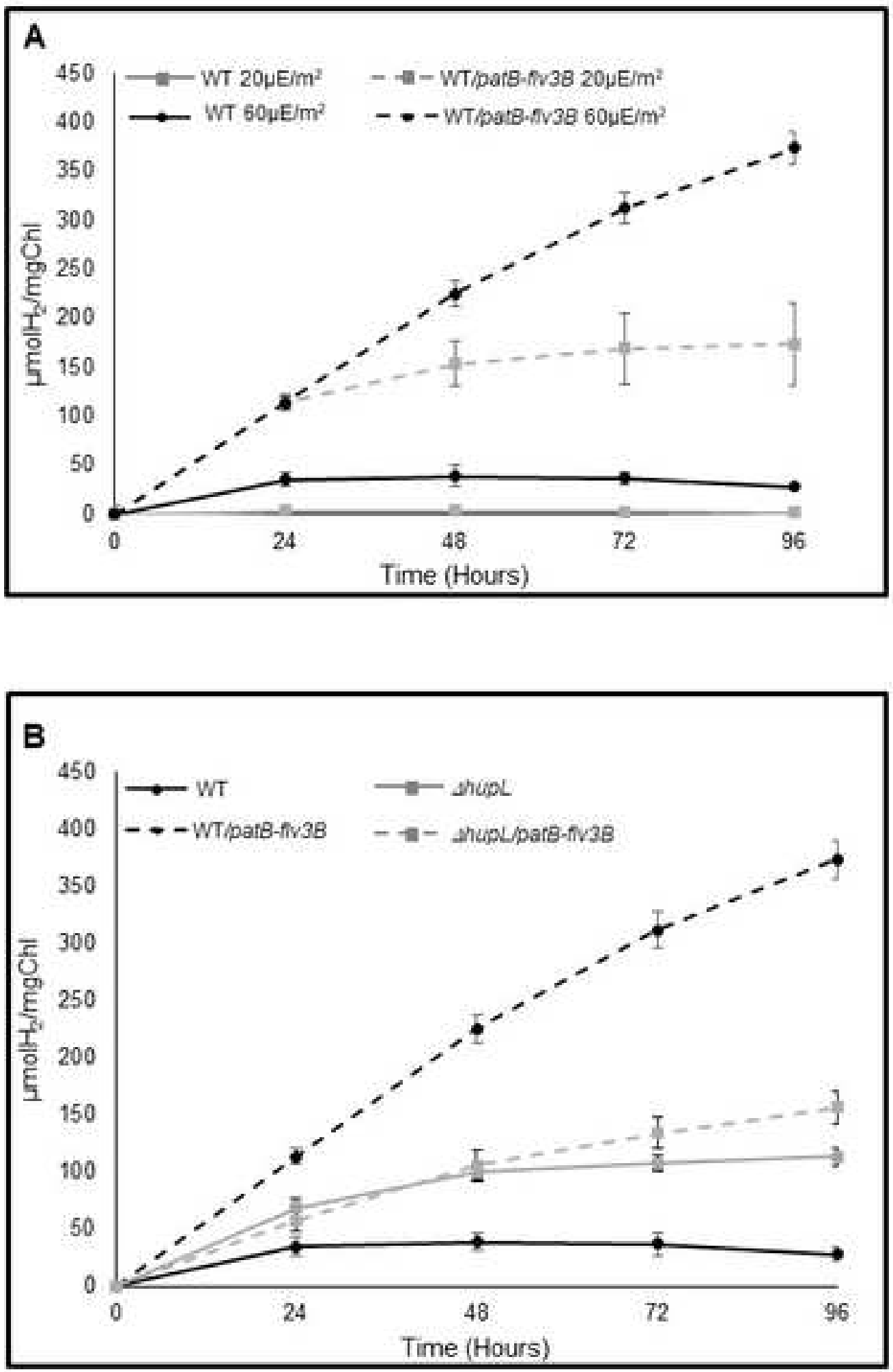

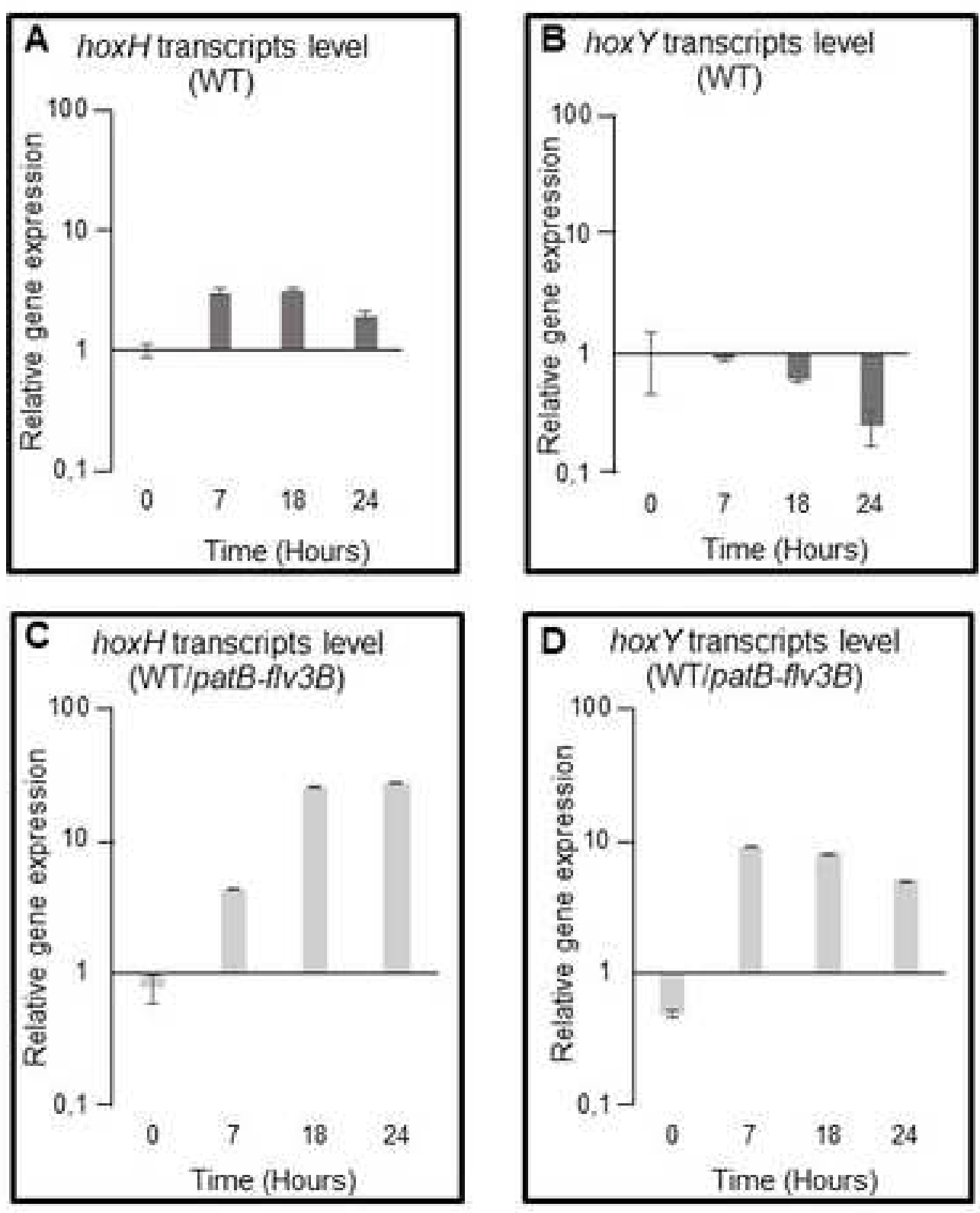

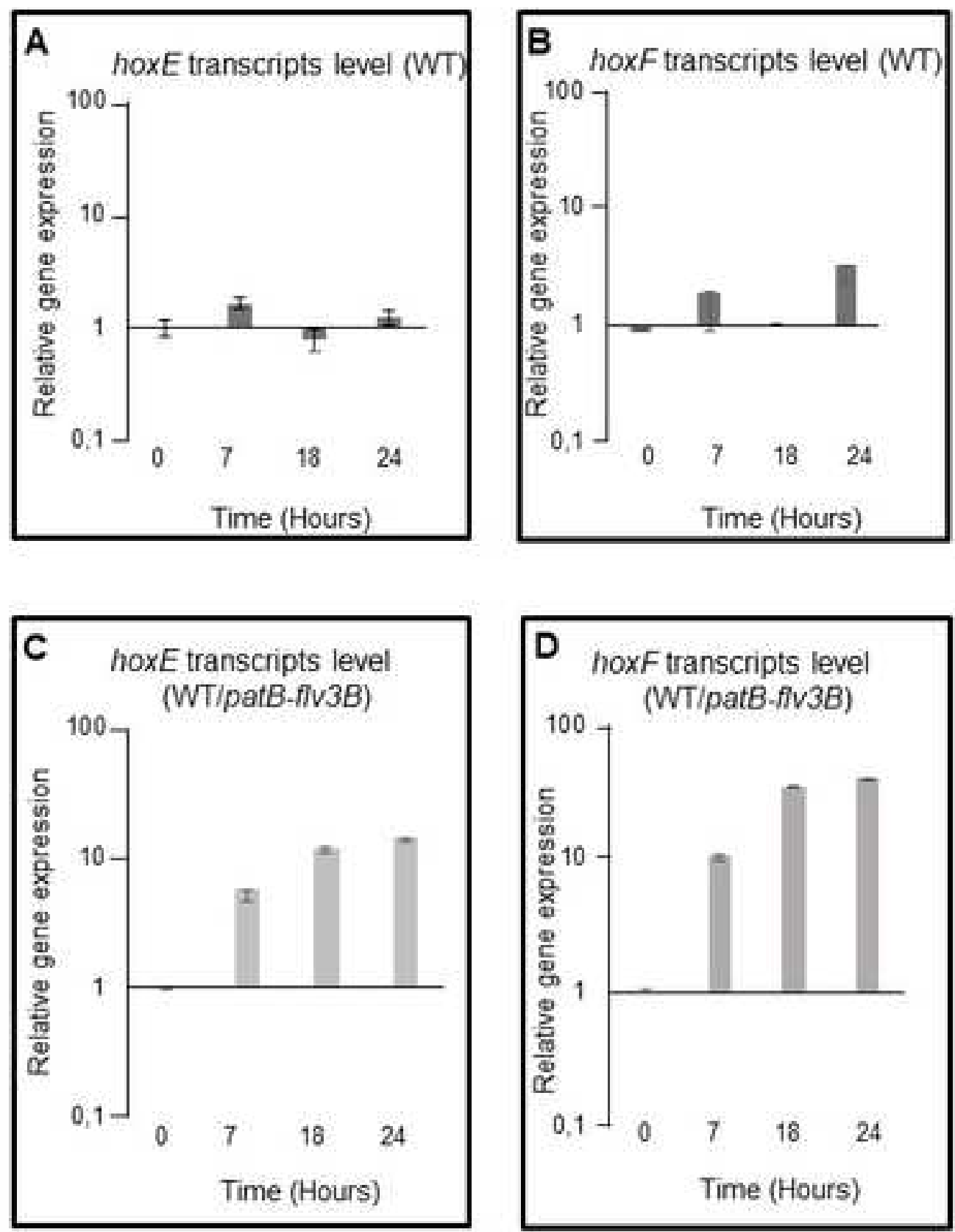

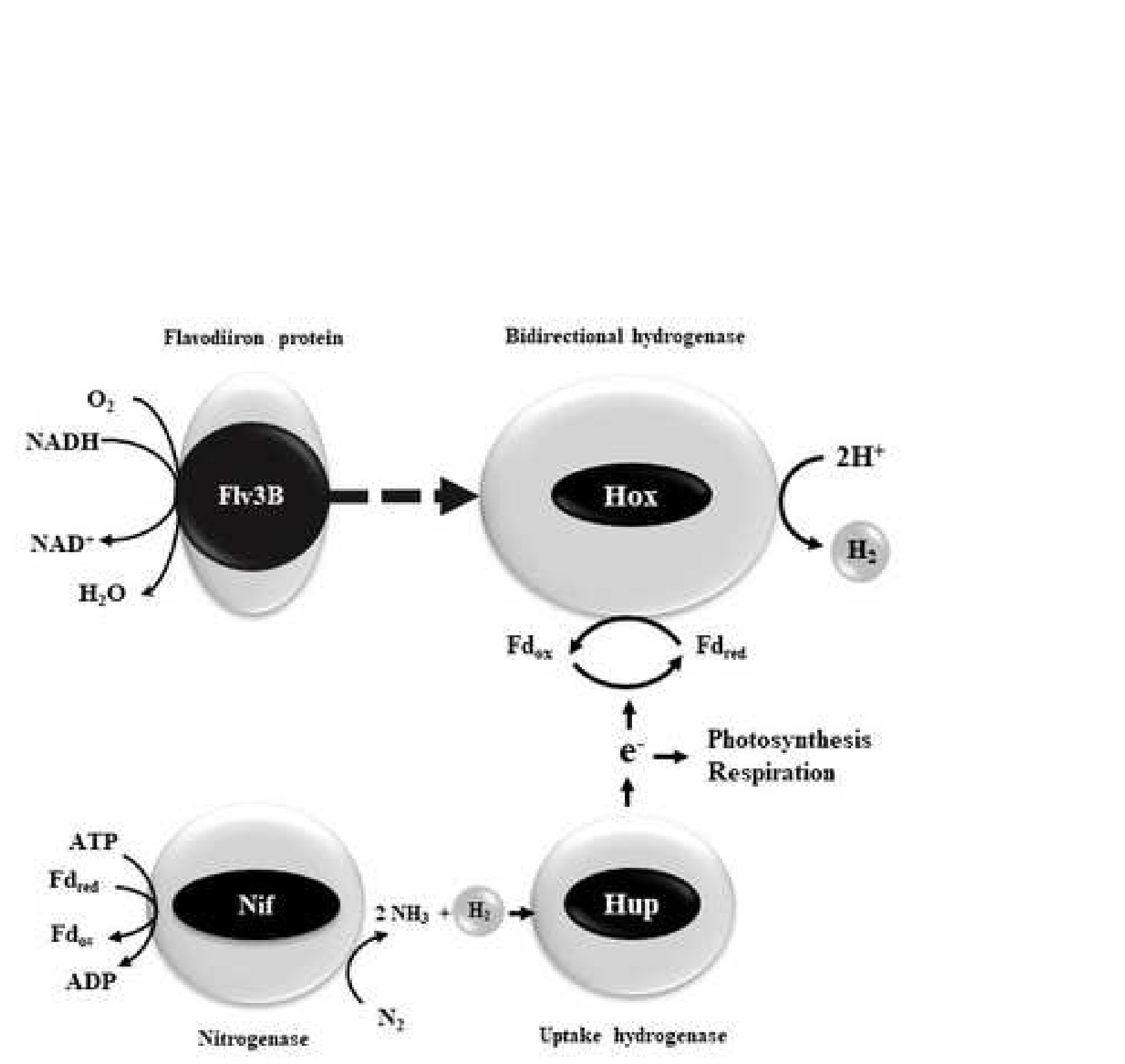


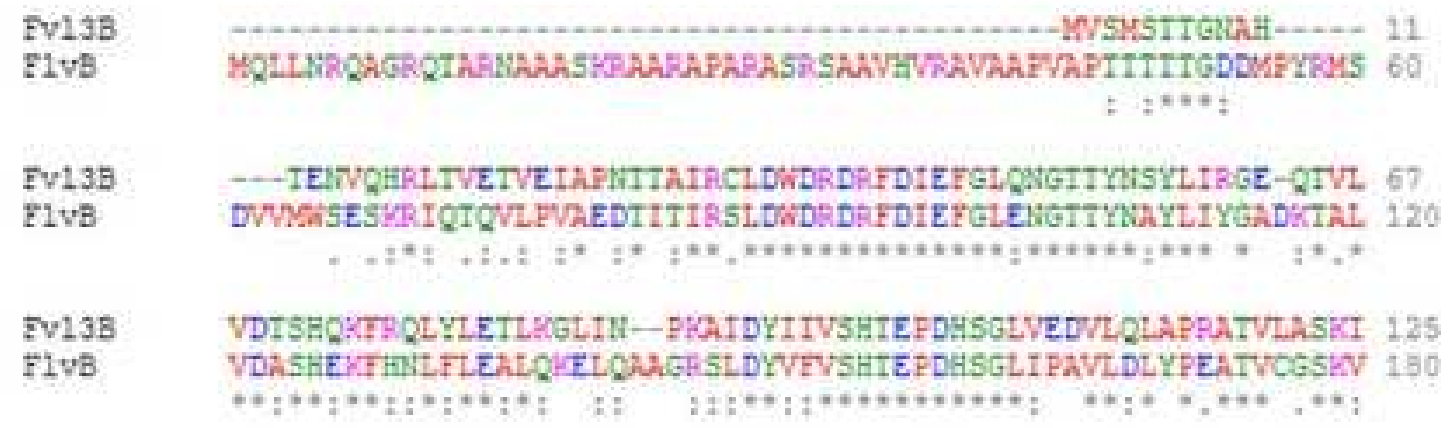

FV135 ALQFLEGLVHDPFSYRTVKSGDRIDIGKGHEIEFVSAPHLHFDTIFSYDKKTEVIYCD 195

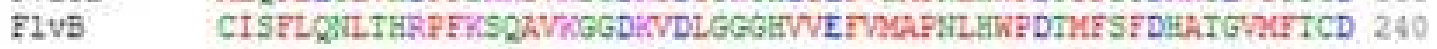

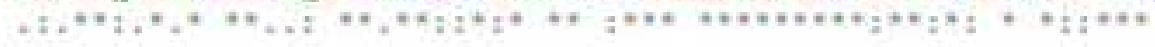

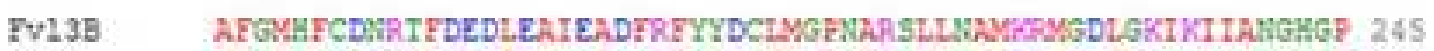
YLVB AFGMYCSEQPFDADVNVMPHYRYYYCLNKFNAKSVTIALFWVYDLP-YTAIANGHGF 299

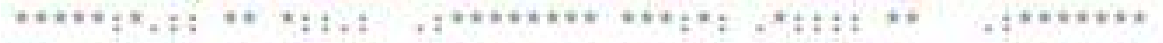

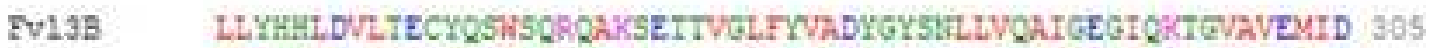
FLVB ILRYIVSLVGDYGRSAATMGATSVAVYASDYGFSDRLSOTLARGTTIOGVATEMLD 359

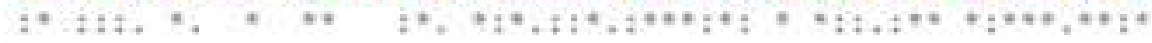

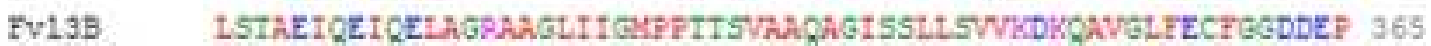

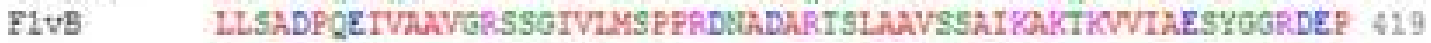

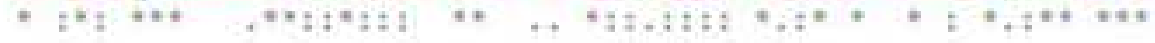

Ev13B VDTIRPKFIDLGVEKFATRIKDVFGSAYQLCTEAOTDLOQLITERUTKOI-ICSLDV 424

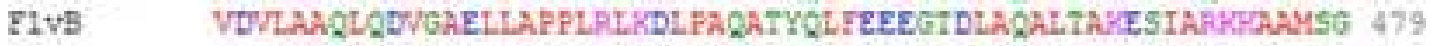

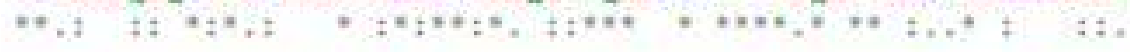

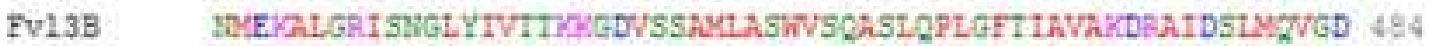

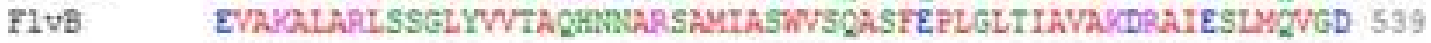

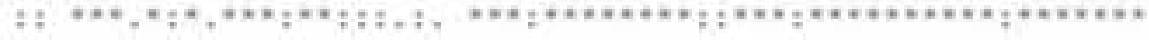

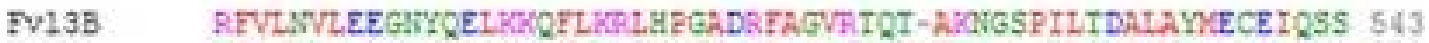

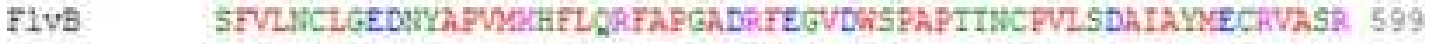

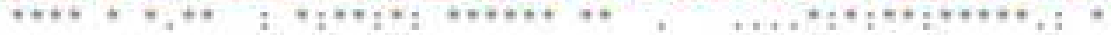

FV13B LECSDHYTLYCTVEDGRSKPDGLTAVRHAKVGIYY 379

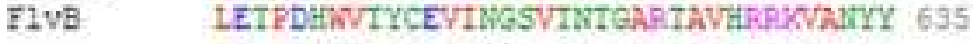

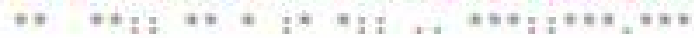

